Saudi Journal of Humanities and Social Sciences

Abbreviated Key Title: Saudi J Humanities Soc Sci

ISSN 2415-6256 (Print) | ISSN 2415-6248 (Online)

Scholars Middle East Publishers, Dubai, United Arab Emirates

Journal homepage: http://scholarsmepub.com/sjhss/

Original Research Article

\title{
Relationship between Contextualised Understandings of God the Role of Paranormal Religious Experiences among Akurinu Believers in Nairobi County
}

\author{
Simon Nderitu Wambugu*, Esther Kibor \& William Koros \\ Kabarak University, Off Nakuru - Sigor Rd, Nakuru, Kenya
}

DOI: $10.36348 /$ sjhss.2019.v04i11.002 $\quad$ | Received: 03.11.2019| Accepted: 12.11.2019 | Published: 18.11 .2019

*Corresponding author: Simon Nderitu Wambugu

\section{Abstract}

The purpose of this article was to examine the relationship between understandings of God and the role of paranormal religious experiences among the Akurinu believers in Nairobi County, Kenya, as believers who share doctrines, beliefs and practices with other believers in African Independent Churches (AICs). The authentic hermeneutical procedure of interpreting God's objective truth recorded in the Bible is instrumental to believers' access to God's truth. Two theories which guided the study were Divine Command Theory (DCT) and Diffusion of Innovations Theory (DIT). The study adopted mixed methods research which used descriptive research design. The study was conducted among believers sampled from Akurinu congregations registered with General Conference of Akurinu Churches Assembly (GeCACA) in Nairobi County. The study targeted population of 2600 Akurinu believers. A sample size of 336 Akurinu believers and 18 leaders was selected using simple random, proportionate and purposive sampling techniques, respectively. Validity and reliability were ensured through piloting and expert advice and piloting of instruments. Data were analysed using Software Package for Social Sciences (SPSS), version 22.0, to generate multivariate linear regression model at alpha $=0.05$ and findings presented in tables, frequencies, percentages and inferential statistics. The results indicated a strong positive correlation at $\mathrm{r}=0.659$, which justified acceptance of an alternative hypothesis. The findings would help Akurinu leadership apply authentic hermeneutical principles which would increase the accuracy of God's truth accessed objectively from biblical texts and applied as biblical contextual theology by Akurinu believers.

Keywords: Contextual theology, contextualisation, diffusion, divine commands, paranormal religious experiences.

Copyright @ 2019: This is an open-access article distributed under the terms of the Creative Commons Attribution license which permits unrestricted use, distribution, and reproduction in any medium for non-commercial use (NonCommercial, or CC-BY-NC) provided the original author and source are credited.

\section{INTRODUCTION}

Ideally, Church leaders should use this truth to inform other Christians on all matters of doctrine, faith and practice, work, ethics, divine communication and resulting lifestyle as contextual theology that reflects a biblical understanding of God. However, reliance on paranormal religious experiences (prophecy, dreams and visions) among Akurinu believers as a source of subjective communication from God tended to minimise the role of God's word as the only source of objective truth needed to guide their lifestyle, referred as contextual theology in this article. The problem was lack of biblical accuracy in a contextualised understanding of God among Akurinu believers and non-Akurinu communities. Internal complaints expressed by Church leaders in the General Conference of Akurinu Churches Assembly (GeCACA) constitution and by-laws [1] indicate need for restoration of "One
Church, One Calling, and One Faith: United in purpose and mission" which reflected differences in understanding of God in the lifestyles of believers due to lack of means of accessing God's timeless truth to guide believers in meeting their ever-changing contextual needs. If this problem continued, the impact of expressed concerns would have continued. This study examined the relationship between understandings of God and the role of paranormal religious experiences among Akurinu Believers in Nairobi County.

\section{LITERATURE REVIEW}

The Hebrew verb for understanding, biyn, בִּין, means to separate mentally, to discern, to have insight [2]. Since God is self-revealing within the context of redemptive relationships, $\mathrm{He}$ initiates with human beings, ways of establishing and sustain that 
relationship is instrumental to human understanding of God. Burke [2] conducted a study in the United States to establish indicators of true spirituality in relation to daily walk with God. The findings revealed that the fastest numerically growing churches offered self-help programmes which met personal existential needs at temporal level without true fellowship with God in ways that would enable believers to get insight on who God is (God's nature) in order to expect Him to act consistently in certain ways in their lives (God's character).

Knowing God at an intellectual level can be acquired through what He has said about Himself in the attributes. Understanding God is the relational level, and effective communication is instrumental to any sustainable relationship. Lord [3] illustrates every believer's need for God's guidance in daily life by using Global Positioning System (GPS) analogy. The one who knows the destination but does not know the ways gives a destination to GPS. This analogy falls short as a way of knowing God because humans often lack knowledge of God's destination for them. The believer is to simply ask God to lead him or her to His destination through effective communication of accurate listening to God, hearing Him and following Him through obedience by faith. However, Lord [3] highlights four universal truths as a rationale for understanding God. First, everyone ends up somewhere after a phase of a journey in life, but few does it intentionally. Second, two people cannot walk together unless they agree on a common destination. Third, decisions believers make influence that they become later. Fourth, human decisions are made based on the perceived destination. Applying these truths to use of dreams, visions and prophecy by Akurinu believers to determine God's paths and destinations for their lives is less certain than GPS due to variability of interpretation of these means of communications between a believer and God. As attested to in the biblical accounts, sources of dreams, visions and prophecy, sources of these experiences are personal and therefore lacking objective understanding of God on His pathways, purpose, intentionality and destiny (Prov. 16:9; Prov. 14:14; Amos 3:3 and 1 Sam.3:10). To Akurinu believers, God speaks more frequently and authoritatively through dreams, visions and prophecy.

Guthrie [4] claims that Jesus spoke to people through miracles He performed. However, Jesus used many ways to speak to people, including actual words of instruction (Matt. 5:1-13). Understanding of God is limited when a believer puts God into one means of self-revelation through His communications as Akurinu believers noted by Guthrie [4] and principles noted by Lord [3] attempts to confine God. However, God's ways and thoughts are different from those of mankind unless mankind is aided by God to discern those ways and walk in them. In spite of shortcomings of these attempts, every believer needs to make an effort to understand God and His ways in order to contextualise correct understanding of God through accurately in different contexts of daily life. Packer [5] notes that seeking to grow in understanding God through his daily communications improves contextualisation of God's truth in daily life in the world, which God understands perfectly as its creator.

Mbiti [6] comments on the understanding of God from African concepts of God are that religion is a way of life, and it must be experiential. Nationalistic movements in Africa stirred up African theologians to lead a parallel Christian movement which adopted different names such as inculturation, liberation different. The noun prophet in Hebrew is nabi, נביא, from the root "to bubble forth as from a fountain" as he gives people message from God. A prophet is a spokesman for God [7]. The prophetic office was instituted by God when He called Abraham (Gen. 20:7). Marshall, Millard, Packer and Wiseman [8] have outlined characteristics of a true prophet as one who lived a prayerful life.

In the USA, a theologian and church minister, Stone [9] defines a dream as a visual screen through which scenes of events pass while one is asleep. He cites a critical incident of when he slept briefly at $3 \mathrm{pm}$ during the day in 1996; he saw tornado images with five pillars of smoke in a New York City. He shared with some ministers, and an artist drew what he saw. A similar picture came again in 1999. He did not have an interpretation. He looked at drawings in his office again in 2001 and said it looked like a terrorist attack was to happen on the World Trade Centre, and it happened that year in 9/11/2001. Stone contextualised this critical incident of paranormal experience by sharing with others, announcing God's warning and an artist contextualised it by drawing these visions and putting them in Stone's ministry office. Hamon [10] observes that God has always desired to communicate to His people using various means, including prophetic dreams and visions (Numb. 12:6).

A biblical critique based on examples of God's use of dreams to change situations, destinies and bring prophetic knowledge to people was helpful towards the evaluation of biblical and non-biblical contextualisation of dreams. God warned King Abimelech for taking Sarah (Gen. 20:6-7), confirmed to Jacob of time to leave Laban (Gen. 31), revealed to Joseph His future when he was seventeen years (Gen. 37:5-10), Gave Joseph ability to interpret dreams on seven-year famine in Egypt (Gen. 41:), gave Gideon confidence to fight the Midianites (Judg. 7), gave Solomon assurance of answer to his prayer request for wisdom (1Kings 3:512). Stone [9] notes that dreams are signs of a prophet on the basis of John 15:26 and John 16:13.

In Africa, a study was done by Bariu [11] in Roho Churches found out those two main roles of 
prophets is forth-telling current events and foretelling future events. Similar roles were played by biblical prophets in the Old and New testaments. In both contexts, prophets did not tell people what to wear and how to wear. True prophets were apprehended by God in His power to act through them among the people. Their behaviour varied with the historical period, need, place and social and cultural context. Possession behaviour was not always the same. It could sometimes deviate from social norms. A true prophet is fearless, humble, and intercessor [12]. Deke [13] investigated dilemmas the prophets serving in AICs. He found that they are faced with a challenge of trying to integrate traditional means of communicating with spiritual entities through soothsayers, divination, fortune-telling, spirit guides and dependence of the Holy Spirit to bring messages from God and mediate divine healing to the sick in AIC churches. Gunner [14] from the Netherlands studied African Independent churches in South Africa, notably the Zionist church (AmaNazaretha) started by Isaiah Shembe in 1910 in Durban in the region of KwaZulu, Natal. The study revealed that leaders of AICs are regarded as holy prophets, especially the founding leaders, unlike those of Black churches whose focus is liberation from social, economic and political oppression. Isaiah Shembe was called the man of heaven. Usually, one of the children of prophetic leaders carries on with ministry based on implicit African understanding of the inheritance of a parent by a son or sons. Girls and women usually wear white gowns as a sign of holiness, as was the case AmaNazaretha church. Literacy was associated with modern technology and secularism. Early AICs drew margins and centres in their contextual theology. Separation from the world and anchor of life on the Holy Spirit and His manifestation in dreams, prophecy and visions were key features. The emphasis in this AIC theology and spirituality was that they understood God as a communicator but in limited ways, especially paranormal experiences.

Kärkkäinen [15] conducted a study of AIC founded by Bishop Samuel Mutendi of Zion Christian Church in Zimbabwe. The findings revealed dynamic pneumatology leaning towards liberation from Western colonisers as one of the roles of the Holy Spirit. Second, the role of the Holy Spirit is to liberate people from any form of bondage, poverty included. Third, the Holy Spirit is healer and life-giver for the holistic wellbeing of believers, including good harvest in agricultural activities. Fourth, the Holy Spirit diagnosed sicknesses through AIC prophets and brought healing to the sick. Fifth, the founding bishop emphasised on the Holy Spirit working with prophets to cleanse communities. These findings indicated a contrast with AmaNazaretha believers who were more otherworldly. That is how they understood the mission of God as one who calls out of this world while still in this to live other-worldly. Zionists in Zimbabwe understood God as one who contextualises Himself among believers to improve their wellbeing in this world.

Sundkler [16] studied the African Methodist Episcopal Church as one of the Ethiopian AICs. His findings revealed that: the role of the Holy Spirit was to empower AIC believers to pray so that He can manifest Himself in Charismatic ways. Contextualisation of understanding of God is shaped by tradition, culture, economic and political experience. To Sundkler, theology is done in public in ways that are critical and contextual activity. Second, theology is a linguistic activity. Semantics (the meaning of the language used) cannot be overlooked while theologising. Third, theology is an inter-subjective activity. Finally, theological activities take place on earth. How were these findings relevant to the understanding of God among Akurinu believers?

General Conference of Akurinu Churches [1], main Akurinu tradition on God's means of communication using dreams, visions and prophecy were affirmed and defined. However, sources of doctrines informing Akurinu's use of using dreams, visions and prophecy were considered subjective. There was no focus on any area in which the role any AIC group of prophets were studied in their field of practice, as Kärkkäinen[15] notes.

\section{METHODOLOGY}

The study adopted mixed methods research which used descriptive research design. The study was conducted among believers sampled from Akurinu congregations registered with General Conference of Akurinu Churches Assembly (GeCACA) in Nairobi County. The study targeted a population of 2600 Akurinu believers. This target population included some Akurinu believers who are part of the national leadership team of the clergy. A sample size of 336 Akurinu believers and 18 leaders was selected using simple random, proportionate and purposive sampling techniques, respectively. Response rate data were collected between May and July 2019 through distribution and supervised the administration of three hundred and thirty-five (336) questionnaires. Three hundred and two (302) were returned. The response rate was, therefore, ninety per cent $(90 \%)$. Validity and reliability were ensured through piloting and expert advice and piloting of instruments. Twenty-nine questionnaires were administered in African Holy Ghost Christian Church (AHGCC) at Mwihoko, a branch of one of the sampled congregations in Nairobi County. Cronbach's Alpha test was performed using SPSS-assisted analysis. Results were an alpha of 0.712 (70\%). Data were analysed using Software Package for Social Sciences (SPSS), version 22.0, to generate multivariate linear regression model at alpha $=0.05$ and findings presented in tables, frequencies, percentages and inferential statistics. 


\section{FINDINGS AND DATA ANALYSIS}

Eighteen (18) church leaders were sampled purposively as the participants in the in-depth oral interviews. Their statements were recorded, transcribed and analysed thematically in Tables 1 and 2. The purpose of interviews was to investigate what paranormal experiences said about God because they were used inferentially.

Table-1: Analysis of Data from Oral Interviews with Church Leaders

\begin{tabular}{|c|c|c|}
\hline Text & $\begin{array}{l}\text { Designation } \\
\text { code }\end{array}$ & Emergent themes \\
\hline $\begin{array}{l}\text { Dreams and visions are interpreted by gifted people. We act on prophecies. We } \\
\text { prayed to God to resolve political crisis last elections. God answered our } \\
\text { prayer. }\end{array}$ & $\begin{array}{l}\text { Senior Bishop. } \\
\text { Clergy C1. }\end{array}$ & $\begin{array}{l}\text { Obedience to God. } \\
\text { Gifted believers. Critical } \\
\text { incident. Prayer. }\end{array}$ \\
\hline $\begin{array}{l}\text { Dreams and visions are given to elders recognised in the congregation as gifted } \\
\text { to interpret according to the scriptures through how often one is used by God } \\
\text { and how specific the message is. Elders pray and provide answers from God. }\end{array}$ & $\begin{array}{l}\text { Archbishop. } \\
\text { Clergy C11 }\end{array}$ & $\begin{array}{l}\text { Church leaders. } \\
\text { Gifts of the Holy Spirit } \\
\text { in believers. Prayer. }\end{array}$ \\
\hline $\begin{array}{l}\text { Those who dream or see visions share with elders who take these messages to } \\
\text { the pastor. The pastor prays and relies on personal experience to get meaning. } \\
\text { Dreams are compared with teachings in the Bible to guide meaning. }\end{array}$ & $\begin{array}{l}\text { Archbishop. } \\
\text { Clergy C12. }\end{array}$ & $\begin{array}{lr}\text { Prayer. } & \text { Clergy } \\
\text { experience. } & \text { Biblical } \\
\text { sources. } & \\
\text { Church leaders. } & \end{array}$ \\
\hline $\begin{array}{l}\text { Dreams are given to the elders for interpretation. Elders compare the dream } \\
\text { with experiences and the teachings in the Bible. Prophecies are acted upon. } \\
\text { Visions are clear. }\end{array}$ & eer $(\mathrm{M})$ & $\begin{array}{l}\text { Leader's experience. } \\
\text { Biblical teachings. }\end{array}$ \\
\hline $\begin{array}{l}\text { Dreams are recorded by the church secretary, given to leaders to pray for } \\
\text { interpretation from God and then take action. }\end{array}$ & $\begin{array}{l}\text { Bishop }(\mathrm{M}) \\
\text { Clergy C7. }\end{array}$ & $\begin{array}{l}\text { Church leaders. Prayer. } \\
\text { Obey God. }\end{array}$ \\
\hline $\begin{array}{l}\text { Relying on the Holy Spirit, use allegory, through ministry meaning given by the } \\
\text { pastor. }\end{array}$ & $\begin{array}{l}\text { Bishop. Clergy } \\
\text { C8. }\end{array}$ & $\begin{array}{l}\text { Holy Spirit. Allegory. } \\
\text { Church leaders. }\end{array}$ \\
\hline $\begin{array}{l}\text { Going to the spirit world of the prophet while he or she is prophesying and } \\
\text { interpreting to the people. Dreams come in pictures. Most pictures have } \\
\text { conventional meanings in the church; for example, in a dream, the vehicle } \\
\text { represents the church. }\end{array}$ & $\begin{array}{l}\text { Bishop }(\mathrm{F}) \\
\text { Clergy } \mathrm{C} 14 .\end{array}$ & ory. \\
\hline $\begin{array}{l}\text { dream, vision or prophecy if it is for the church, takes it } \\
\text { leadership prays and gives direction to the believer. }\end{array}$ & $\begin{array}{ll}\text { Senior } & \text { Pastor } \\
(\mathrm{M}) . & \text { Clergy } \\
\text { C2. } & \end{array}$ & Prayer. \\
\hline $\begin{array}{l}\text { Dreams, visions and prophecy are shared with the secretary, given to church } \\
\text { leaders for prayer to get direction from God. Cheater in a dream was recently } \\
\text { interpreted by a prophet to indicate witchcraft. }\end{array}$ & $\begin{array}{l}\text { Pastor }(\mathrm{M}) \text {. } \\
\text { Clergy C3. }\end{array}$ & $\begin{array}{l}\text { Church leaders. } \\
\text { Imagery/allegory. }\end{array}$ \\
\hline In some c & ${ }^{(\mathrm{M})}$. & Prayer. \\
\hline that concern several people or congregation are & $\begin{array}{l}\text { Pastor }(\mathrm{M}) \text {. } \\
\text { Clergy } 10 .\end{array}$ & $\begin{array}{l}\text { Gifts of the Holy Spirit } \\
\text { in believers. }\end{array}$ \\
\hline $\begin{array}{l}\text { Use the Bible to check for alignment of meaning. Use experiences of church } \\
\text { leaders, pray." }\end{array}$ & $\begin{array}{l}\text { Pastor }(\mathrm{M}) \\
\text { Clergy C5. }\end{array}$ & $\begin{array}{l}\text { Bible. Church leaders. } \\
\text { Prayer to God. }\end{array}$ \\
\hline through pra & $\begin{array}{l}\text { h }(\mathrm{M}) \text {. } \\
\text { er Y6. }\end{array}$ & rch leaders. \\
\hline $\begin{array}{l}\text { Prophecy, dreams and visions are inter } \\
\text { from God. Youth Y9. }\end{array}$ & $\begin{array}{l}\text { Youth }(\mathrm{M}) \text {. } \\
\text { Leader Y9. }\end{array}$ & Holy Spirit \\
\hline Use of gifted leaders & $(\mathrm{M})$ & believers. \\
\hline $\begin{array}{l}\text { There are rules. You pass through the pastors and explain. Pastor helps you to } \\
\text { know whether the dream is for the congregation or personal. Only visions come } \\
\text { from God always. In the early days, people were holy. Prophecies and dreams } \\
\text { were always from God. I have never experienced a prophecy. }\end{array}$ & $\begin{array}{l}\text { Youth }(\mathrm{F}) . \\
\text { Leader Y16 }\end{array}$ & $\begin{array}{l}\text { Church leaders. } \\
\text { Continuity and change. } \\
\text { Critical incident. }\end{array}$ \\
\hline $\begin{array}{l}\text { Dreams and visions are reported to leaders, recorded and raised to God in } \\
\text { prayer, waiting for interpretation and fulfilment. Critical incident: Recently, } \\
\text { parents of my husband were told by a believer in the congregation that 'I dreamt } \\
\text { that a boy child was being taken away from parents by one of two other people } \\
\text { who were making efforts to take him.' It has not been fulfilled. We are waiting. }\end{array}$ & $\begin{array}{l}\text { Pastor's wife. } \\
\text { PW } 17 .\end{array}$ & $\begin{array}{l}\text { ch leaders. } \\
\text { lent. }\end{array}$ \\
\hline $\begin{array}{l}\text { Prophecy, dreams and visions are common in our church. Not everyone } \\
\text { interprets. Critical incidents: For dreams. I pray and search in my phone for } \\
\text { help because there are posts from some people who write guidelines on how to } \\
\text { interpret dreams. }\end{array}$ & $\begin{array}{l}\text { Overseer's } \\
\text { wife. OW } 18 .\end{array}$ & $\begin{array}{l}\text { Gifted believers. Critical } \\
\text { incident. } \\
\text { Social media and } \\
\text { theology. }\end{array}$ \\
\hline
\end{tabular}


Oral reports from church leaders were recorded, transcribed, categorised into main themes and thematic analysis made in Table- 2 .

Table-2: Thematic Analysis of Oral Interviews with Church leaders (O.I. 1)

\begin{tabular}{|l|l|l|l|}
\hline Emergent theological theme to guide interpretation & Frequency & Per cent & Rank \\
\hline Prayer to God for interpretation of paranormal & 10 & 28 & 1 \\
\hline Church leadership as priests for the other believers & 9 & 25 & 2 \\
\hline Gifts of the Holy Spirit in believers who obey God & 7 & 19 & 3 \\
\hline Critical incidents/ living experiences & 4 & 11 & 4 \\
\hline Bible dream symbols interpreted allegorically & 3 & 8 & 5 \\
\hline Continuity and change/ declining spirituality concern & 2 & 6 & 6 \\
\hline Interpretation guidelines in social media & 1 & 3 & 7 \\
\hline Total & 36 & 100.0 & \\
\hline
\end{tabular}

\section{Inferential Statistics}

Table-3: SPSS Output on Analysis of Independent and Dependent Variables

\begin{tabular}{|l|l|}
\hline Variable /constant & Role of paranormal experiences \\
\hline Understandings of God & 0.695 \\
\hline Constant & 0.639 \\
\hline Observations & 302 \\
\hline
\end{tabular}

\section{DISCUSSION}

In Table-2, illustrative statements and critical incidents shared as personal experiences were discussed.

Dreams and visions are interpreted by gifted people. We act on prophecies. We prayed to God to resolve political crisis last elections. God answered our prayer (Senior Bishop. Clergy C1.).

This finding corresponds to the findings by Kärkkäinen [15] in his study of religious phenomena in Zion Christian Church in Zimbabwe. Only through the gifted, the prophets, would the Holy Spirit reveal the sickness. The testimony of the senior Bishop using the critical incident of God summoning a team of Akurinu clergy to pray and fast so that God resolve the political crisis and He did. This critical incident further showed that Akurinu believers understood God as an effective communicator through dreams, visions and prophecy at the expense of other means of communication. Kraft [17] argues that Jesus is the New Testament communicator to people (Heb. 1:1-3). This theological statement does not correspond to paranormal experiences of Akurinu believers who understand God as the communicator to them through dreams, vision and prophecy.

Findings in Table-2 showed that prayer to God for the interpretation of paranormal experiences ranked majority (28\%). One of the Akurinu writers [18] notes that prayer formed "the very important part of Akurinu worship and life" as part of their call in Matthew 6:5-6. Every believer was expected to pray for the interpretation of dreams, visions, prophecy that came in symbols and more. Wood [19] argues that the interpretation of actual words of the participants informs judgments made about them. Actual words of Akurinu believers revealed how they interpreted dreams, prophecy and visions as God's means of instructions given to them on matters of daily living. The send in rank $(25 \%)$ was believers affirmed that church leadership as priests for the other believers who interpreted dreams, visions and prophecy for Akurinu believers.

Comparing the sampled finding of an elderly senior Bishop with finding from a female youth revealed a spiritual paradigm ship towards secularisation of the Akurinu church. The statement.

There are rules. You pass through the pastors and explain. Pastor helps you to know whether the dream is for the congregation or personal. Only visions come from God always. In the early days, people were holy. Prophecies and dreams were always from God. I have never experienced a prophecy.

Based on this single comment, God was understood as legalistic. Any believer who got a dream needed to report it to the pastoral team for vetting and interpretation. According to 1Pet. 2: 1-10, every believer in Jesus Christ is a priest, meaning that each Akurinu believer needed to approach God directly for interpretation of dreams, visions and prophecy. The role of the clergy would have been to train very Akurinu believer to understand God directly by training them to correlate with scriptures, pray to God for interpretation and learn how to contextualise God's communications. The youth expressed that people were holy in the early days. Early was relative in that she might have been referring to her childhood days of the late 1980s. The believer did not have an experiential dimension of prophetic ministry as a youth leader. This finding suggested that there was a lack of continued godliness. However, lack of personal experience might have been due to spirituality of her congregation or personal walk with God or lack of need for God to speak to her in 
prophecy since the Bible gave direct and objective truth.

\section{Inferential Statistics}

The study was based on the hypothesis given below: $\mathrm{H}_{0}$. There is no statistically significant relationship between understandings of God and the role of paranormal experiences among Akurinu believers.

The results from the regression model indicated a positive and statistically significant relationship. The results indicated that a unit increase in understanding of God predicted an increase in the role of paranormal by 0.695 . The alternative hypothesis was, therefore accepted as statistically significant at a $95 \%$ level of significance. Hence the study rejected the null hypothesis and concluded that there was a statistically significant relationship between understandings of God and the role of paranormal experiences among Akurinu believers. Decision taken was to fail to accept the null hypothesis and accept the alternative, which was an affirmation that there was a strong positive linear relationship between understandings of God as one who speaks to Akurinu believers through paranormal experiences. The regression model was explained by the equation: $\mathrm{Y}=0.639+0.695 \mathrm{X}$.

\section{CONCLUSION}

Several conclusions emerged from findings, literature and biblical evaluation. First, though prayer is the best response to the interpretation of paranormal experiences, it should not be made a mandatory strategy. Second, the fact that God showed to Pharaoh seven years of plenty of food followed by seven years of famine confirms that God may use paranormal experiences to reveal current or future to unbelievers, though interpretation may be done by a believer whom God chooses as He did with Joseph. Third, based on this top frequency in Table-2, Akurinu believer's used prayer was an indicator of their contextualisation of paranormal religious experience in Nairobi County. Based on findings, Church leaders needed to teach everyone objective principles of biblical hermeneutics as an effort to contextualise theology biblically. GeCACA needed to oversee the process of transformation and transition of Akurinu Church. Fourth, the differences in theological statements of youths and elderly clergy suggested a lack of effective continuity of Akurinu faith from the older generation to the new. This represented differences in the understanding of God across gender, age and status in ministry, among other variables.

\section{REFERENCES}

1. General Conference of Akurinu Churches Assembly (GeCACA). (2016). Constitution and By-laws. General Conference of Akurinu Churches.

2. Burke, B. (2006). Is God Obsolete? England: Cook Communications ministries.

3. Lord, P. (2011). Hearing God: An easy-to-follow, step-by-step guide to two-way communication with God. Dallas: Chosen Books.

4. Guthrie, N. (2009). Hearing Jesus speak into your sorrow. Illinois: Nav Press.

5. Packer, J. I. (2011). Knowing God. John Murray Press.

6. Mbiti, J. S. (2012). Concepts of God in Africa. $\left(2^{\text {nd }}\right.$ Ed.). Nairobi, Kenya: Acton Press.

7. Atler, A. (2014). The Pentecostal gospel, religion and culture in the African perspective. Pentecostal Theology in Africa - books.google.com

8. Marshall, I. H., Millard, A. R., Packer, J. I., \& Wiseman, D. J. (2010). New Bible Dictionary. ( $3^{\text {rd }}$ Ed.). Nottingham: Inter-Varsity Press.

9. Stone, P. (2011). How to Interpret Dreams and Visions: Understanding God's Guidance. Florida: Charisma House Book Group.

10. Hamon, J. (2000). Understanding your dreams and how God can use them to speak to you today. Ventura, CA: Regal Books.

11. Bariu, R. M. (2018). The function of prophetic foretelling in Roho Christianity. European Scientific Journal, 13(35), 146-160.

12. Grubb, E. (2010). The Characteristics of a True Prophet. Sons of God Ministries. Retrieved from https://www.sogmi.org/articles/the-characteristicsof-a-true-prophet/

13. Deke, A. (2015). The Politics of Prophets and Profits in African Christianity. Journal of Philosophy, Culture and Religion 12(2015), 1124.

14. Gunner, E. (2002). The Man of Heaven and the Beautiful Ones of God: Writings. Netherlands: Library of Congress Cataloguing-in-Publication Data.

15. Kärkkäinen, V. (2002). Pneumatology: The Holy Spirit in Ecumenical, International, and Contextual Perspective. Baker Books.

16. Sundkler, B. (1961). Bantu Prophets in South Africa. England: James Clarke \& Co.

17. Kraft, C., H. (2012). Communicating Jesus' Way. William Carey Library.

18. Macharia, A. (2012): Demystifying the Akurinu community. Nairobi, Kenya: Print view Publishers.

19. Wood, N. (2001). The Health Project Book. London, Routledge. 